\title{
Unique Deep-Water Ecosystems OFF THE SOUTHEASTERN UNITED STATES
}

BY STEVE W. ROSS

If nothing else, research in deep-sea environments teaches us how little we know about such important and productive habitats. The relatively recent discovery of hydrothermal-vent and cold-seep ecosystems illustrates this paucity of knowledge, and the subsequent explosion of research on these systems is a good example of the impact such concentrated efforts can have on marine sciences (see the March 2007 special issue of Oceanography on InterRidge, and Levin et al., 2007). The recent surge of interest in deep-sea corals is another example of how focused research on a particular subject can result in new perspectives on continental slope biotopes. Although deep-sea corals have been known for over 200 years, they were viewed as somewhat of a novelty, and research on them was sporadic, typically geologic, and usually only documented their occurrences (e.g., Stetson et al., 1962; Neumann et al., 1977; Paull et al., 2000).

Over the last 10 years, worldwide research on deep-sea corals, seamounts, and other deep-sea structures has increased significantly, resulting in three international symposia (a fourth is planned for 2008), a variety of review papers (Gass, 2003; Hain and Corcoran, 2004; Morgan et al., 2006; Roberts et al., 2006; Lumsden et al., 2007), and numerous other publications. Likewise, during the last seven years, deep-reef research has also steadily expanded on the southeastern US (SEUS) slope, where deep-sea corals are common (see review in Ross and Nizinski, 2007). Some revelations from these efforts are that: (1) deep-sea corals are widespread on continental margins and seamounts at all latitudes and in all oceans, (2) they and other structures support significant, important, but poorly documented deep-sea centers of biodiversity, (3) the overall area of deep-sea corals probably exceeds that of all known shallow-water, tropical coral reefs, and (4) these ecosystems are at risk from a variety of anthropogenic activities that range from ocean acidifcation (Guinotte et al., 2006) to the general spread of exploitation activities into deeper waters (e.g., fishing, hydrocarbon exploration, mining).

Our research team began studies on continental slope habitats in the early 1990s, concentrating on an unusual canyon system on the Hatteras middle slope (locally known as "The Point;" Figure 1). Driven by interest in oil exploration, this relatively small, biologically and physically unique area became one of the most studied portions of the US continental slope (Diaz et al., 1994; Ross et al., 2001; Bauer et al., 2002). Continuing our research at The Point (Sulak and Ross, 1996), in 1999 we began a whole-watercolumn trophodynamics study and eventually added deep-coral Lophelia pertusa banks and shelf-edge hardground reefs off central North Carolina for community structure comparisons (Figure 1). Ultimately, we added other deep-coral study sites (Figure 1) to better represent the Blake Plateau (Cape Lookout to Cape Canaveral). Because biological data were lacking from the deep-coral systems, our initial objectives were to characterize their fish communities. Study objectives were expanded to include examining 

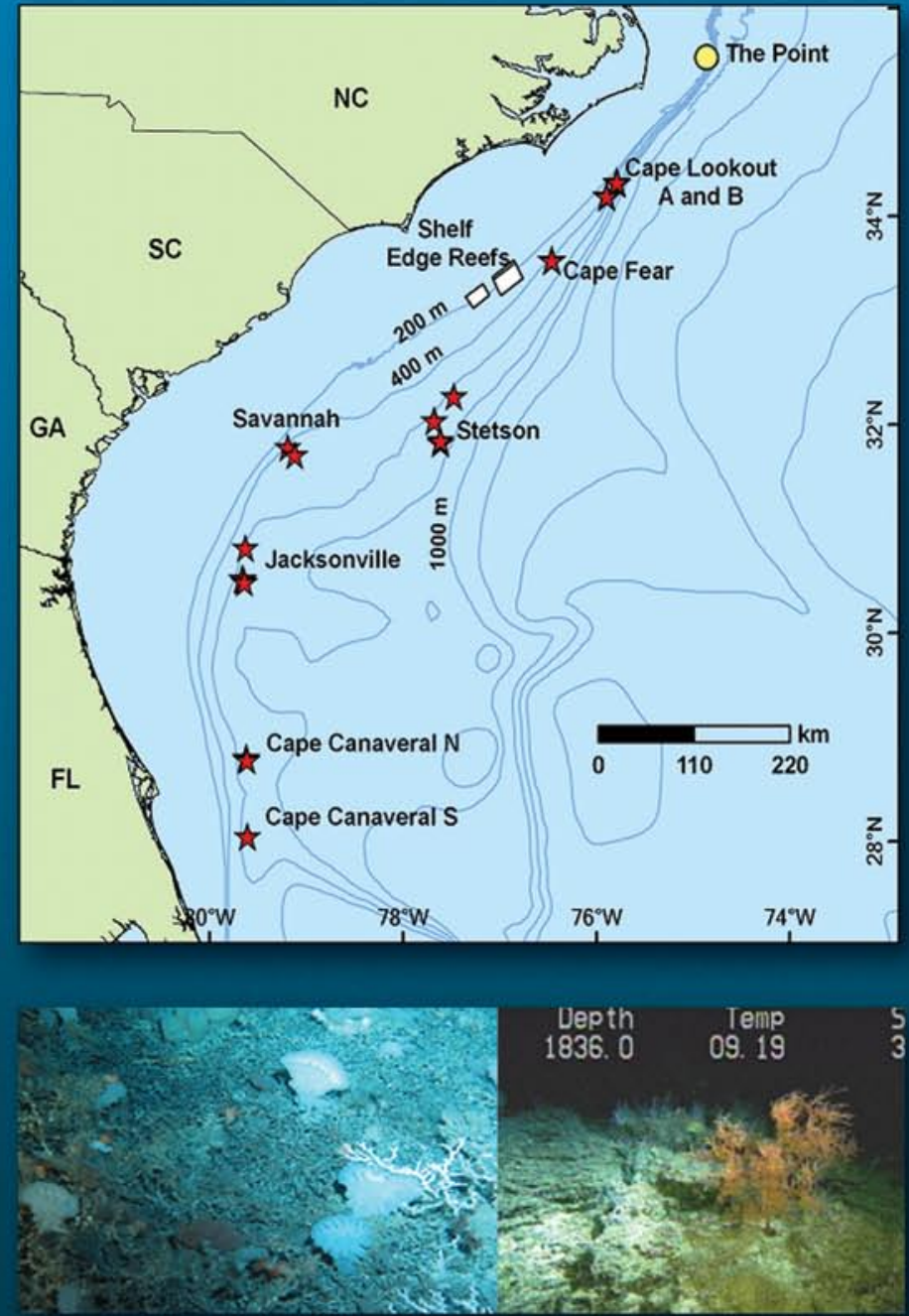

\section{Jacksonville Lithotherms}

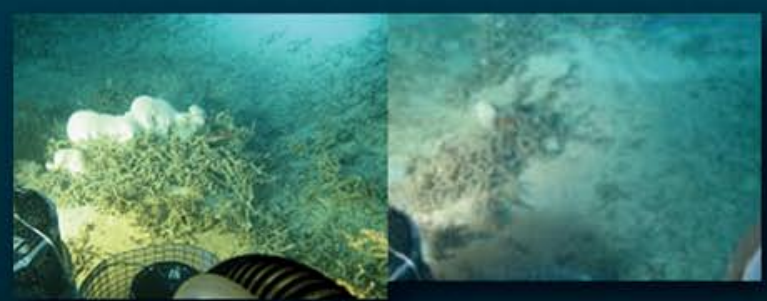

\section{Canaveral Banks}

Figure 1. Map: continental slope and shelf-edge reef (white boxes), deepcoral (red stars), and canyon (yellow dot) study sites of Ross et al. (1991present) off the southeastern United States. Photos: example benthic habitats at these sites. The Point represents a muddy canyon environment with very rugged topography as illustrated in the SeaBeam image of the bottom (far left). The three animals are typical of that area, from top left to right: Phycis chesteri, Lycodes atlanticus, llex sp. The other study areas are all dominated by different types of hard substrata ranging from various types of rocks to hard and soft corals and sponges.
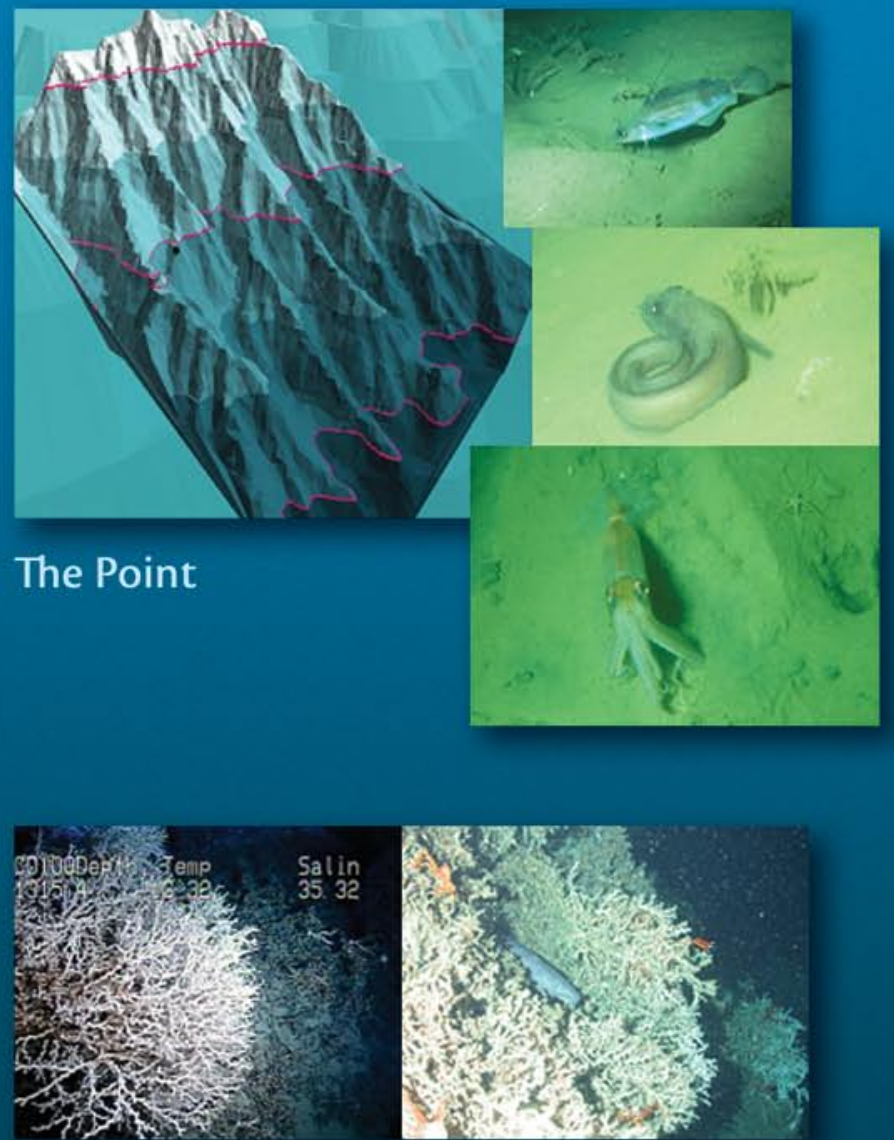

\section{North Carolina Banks}

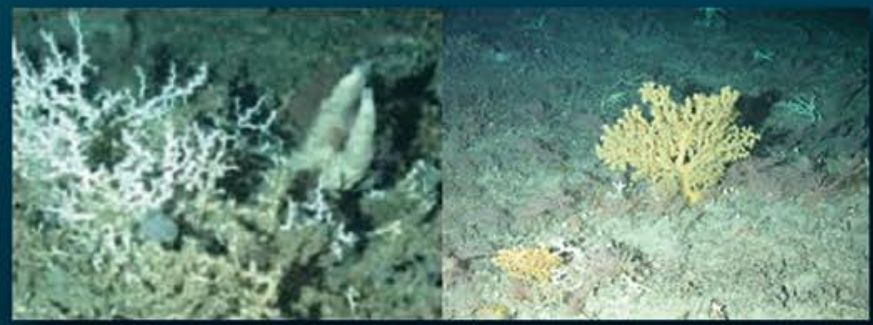

\section{Stetson Banks}

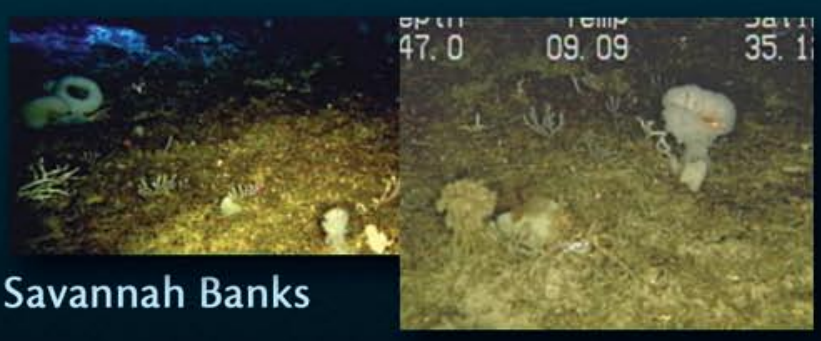


fish distributions over the whole water column, discovery and mapping of deepcoral and reef habitats, distributions and ecology of benthic macroinvertebrates, population structure and taxonomy of corals and other dominant taxa using the Gulf Stream facilitates the maintenance of a productive subtropical reef community on the outer shelf (about 50-100-m depth) as far north as Cape Hatteras.

Although few sweeping generaliza-

During my first multibeam mapping cruise off the SEUS, I learned more concerning the distribution and topography of deep-coral areas in about 30 hours of mapping than in the previous six years using more standard methods.

genetic techniques, and paleoecology using black and bamboo corals as proxies for environmental data.

This paper summarizes parts of our deep-reef research on the slope of the SEUS, emphasizing data from a variety of interdisciplinary projects. Other slope and continental shelf-edge habitats we have studied facilitate wide-area comparisons across different habitats. This review points to a need for further research, especially into the mechanisms that regulate deep-sea slope communities in this region.

\section{SETTING FOR DEEP-REEF} HABITATS OFF THE SOUTH-

\section{EASTERN UNITED STATES}

The marine waters of the SEUS have long been of scientific interest and are well known for economically valuable marine resources. The shelf and slope waters of this region have a diversity of benthic habitats, and warming by tions apply, the continental shelf and slope of the SEUS do share some largescale physical characteristics. Both are unusually broad, tapering at the north and south ends, and both have high percentages of emergent hard substrata. Overall, the SEUS shelf and slope represent a carbonate sedimentary province, where inshore shelf sediments (with higher quartz and shell-fragment content) have more terrigenous origins, and the amount of biogenic carbonate sediment increases with increasing distance offshore (Gorsline, 1963; Pratt, 1968). The shelf and especially the shelf edge (about 80-100-m depth) throughout this region are marked by numerous topographic prominences (Macintyre and Milliman, 1970; Avent et al., 1977; Thompson and Gilliland, 1980), and these hardground habitats of varying profiles provide substrata for attachment of a well-developed, largely subtropical reef fauna (including corals) (Riggs et al.,
1996; SEAMAP-SA, 2001). The Blake Plateau, a platform scoured and shaped by the Gulf Stream (400-1250-m depths; Popenoe and Manheim, 2001), dominates the continental slope through much of the SEUS (Schlee et al., 1979). Deep corals are common along the edges of the scarps and ridges and on the mounds in this region (Stetson et al., 1962; Pratt and Heezen, 1964). The Charleston Bump, a dominant topographic structure of the Blake Plateau, deflects the Gulf Stream seaward and is heavily scoured by this current, exposing hard substrata (Popenoe and Manheim, 2001). The western side of the Blake Plateau, particularly, has been heavily eroded by the Gulf Stream, exposing numerous depressions, Cretaceous to Miocene hard substrata, and mounds (Uchupi, 1967). On the northeastern end of the Blake Plateau, the Blake Ridge contains extensive gas hydrate deposits and the only known methane seep community in this area (Borowski et al., 1997; van Dover et al., 2003). In contrast, the study site on the Hatteras middle slope (The Point) is geologically more like other Middle Atlantic Bight habitats, and is composed of fine sediments and bisected by rugged canyons (canyons are absent in the SEUS region).

The Gulf Stream (or Florida Current) is the dominant oceanographic feature that shapes much of the geology and

STEVE W. ROSS (rosss@uncw.edu) is Associate Research Professor, Center for Marine Science, University of North Carolina Wilmington (UNCW), North Carolina, USA, and is currently assigned (through the Intergovernmental Personnel Act) to the US Geological Survey, Saint Petersburg, FL, USA. 
biology of the outer shelf and slope off the SEUS. This well-known system influences bottom conditions even at continental slope depths by preventing shelf sediment delivery to offshore areas, transporting sediments and biota northward, and facilitating high current speeds $(\geq 2.5$ knots, $125 \mathrm{~cm} / \mathrm{s})$ on the bottom (Pratt, 1968; Popenoe and Manheim, 2001). The Gulf Stream moderates temperature (generally $>27^{\circ} \mathrm{C}$ ) and salinity (generally $\geq 36$ ) over the outer shelf and slope. This complex current meanders (influenced in part by bottom topography) and produces eddies that spin away from the main current (Atkinson et al., 1985; Bane et al., 2001). As the Gulf Stream is deflected offshore away from the shelf edge, particularly by the Charleston Bump, nitrogen-rich, deeper water upwells onto the outer shelf, leading to localized areas of enhanced production, much of which is later transported offshore (Atkinson et al., 1982; Lee et al., 1991). The Gulf Stream has varied in position since the Pleistocene and has alternately uncovered or facilitated burial of bottom substrata suitable for deep-coral settlement (Zarudzki and Uchupi, 1968). Inshore of the Gulf Stream (ca. < 40-m depth), the physics of the continental-shelf water column is dominated by tides, meteorology (e.g., winds, rainfall), and gravity waves (Pietrafesa, 1983; Mathews and Pashuk, 1986).

Compared with oceanography of the upper water column, bottom conditions over most of the slope are not well known. Long-term data are particularly lacking. High current speeds have been reported; however, I have observed that bottom currents can vary tremendously over short time scales and that they are more complex around coral-mound or rocky features and accelerate through valleys and over the tops of mounds/ ridges. Recent multibeam sonar mapping that I have conducted indicates that long-term current scouring helped shape deep-coral mounds off North Carolina (Figure 2), but that conditions are different at the deeper Stetson area. Bottom temperatures around SEUS deep-coral habitats $(370-780 \mathrm{~m})$ range from $5.4^{\circ}$ to $12.3^{\circ} \mathrm{C}$, and bottom salini-
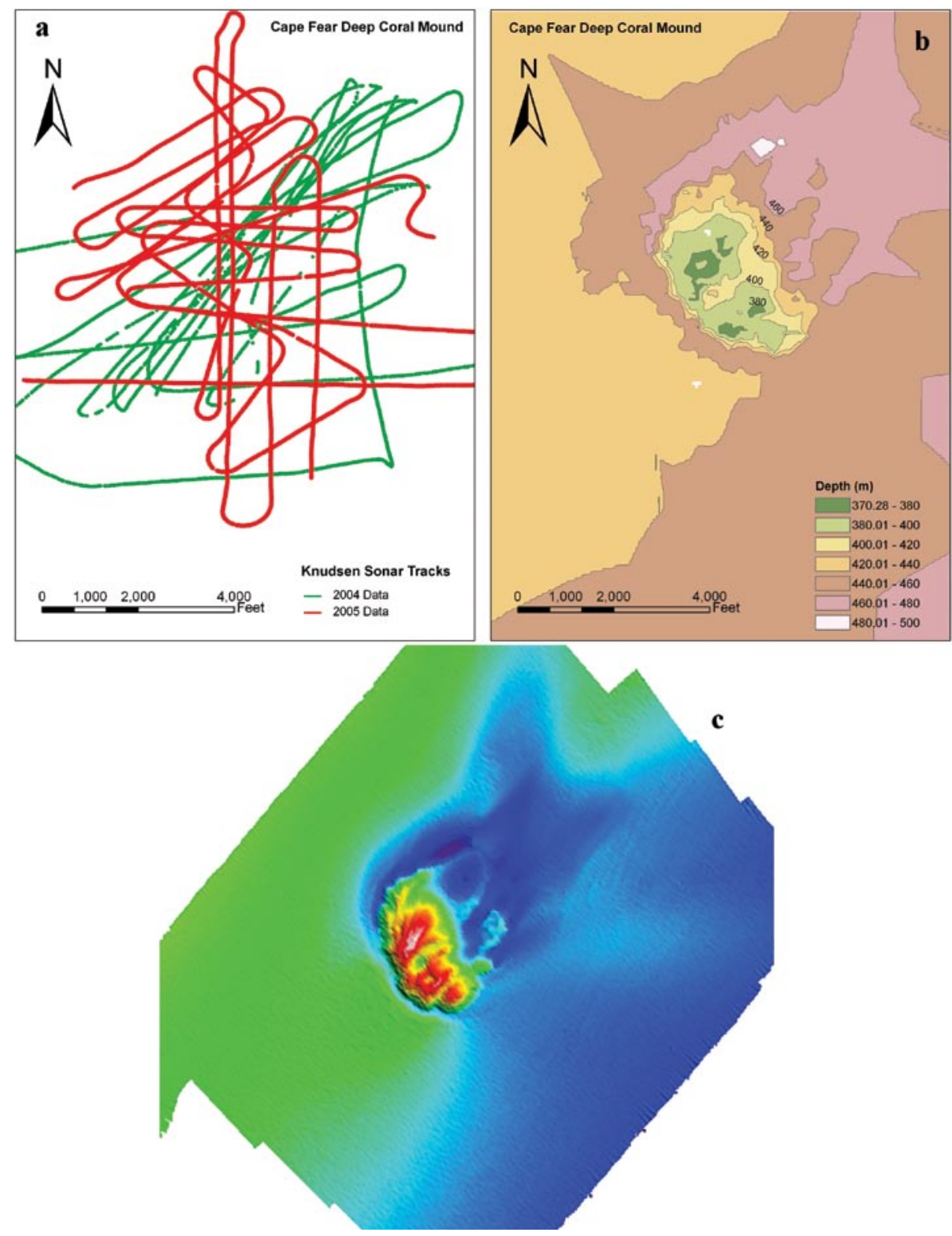

Figure 2. Illustrations of mapping the coral bank off Cape Fear, NC. Many hours of single-beam sonar tracks (a) from two cruises were required to construct a bathymetric map (b). The shaded contour map (c) was produced from about six hours of multibeam sonar mapping in 2006. Note that current scour patterns around the base of this mound are clearly indicated by multibeam data. 
ties vary little from 35 (Reed et al., 2006; Ross and Quattrini, 2007).

Despite the interest in SEUS marine ecosystems, the lack of basic data is surprising. While less true of the shelf (<200-m depth), the biology, ecology, and physics of SEUS at depths from 200 to $2000 \mathrm{~m}$ are poorly documented. The shelf is represented by several historical and ongoing large-scale biological surveys (e.g., Anderson et al., 1956; Bullis and Thompson, 1965, and MARMAP and SEAMAP, the Marine Resources Monitoring Assessment and Prediction and the Southeast Area Monitoring and Assessment programs). In stark contrast, the slope off the SEUS is the only area within the US Exclusive Economic Zone between Canada and Mexico not represented by any large-scale, fisheryindependent databases.

\section{PATTERNS OF FAUNAL}

\section{DIVERSITY}

The SEUS slope is underappreciated as a locus of biodiversity. As noted, this impression is primarily due to a lack of sampling, particularly in deep-coral habitats. Taxonomic studies were not the main focus of our research; however, in pursuing accurate identifications of the species collected and observed, we quickly encountered an array of taxonomic issues. Almost every animal group investigated so far that inhabits SEUS deep-coral habitats has yielded species new to science. One of our collections included a new octocoral species (Thouarella bipinnata; Cairns, 2006) of a genus not previously known in the northwestern Atlantic. Eight other new species of octocorals have also been recently described from this region (Cairns and Bayer, 2004a, 2004b), and more new corals are likely to be discovered as our samples and those of other researchers are analyzed. These investigations should significantly raise the number of deep-sea coral species known (currently 114; Ross and Nizinski, 2007), on the SEUS slope. We subsampled our collections for a preliminary treatment of the hydroids on these coral banks, and even this limited view of hydroids included at least 35 species. Sixty-nine percent of these species provided new distributional data, and two hydroids appear to be new species (Henry et al., in press). An initial appraisal of galatheoid crustaceans (families Galatheidae and Chirostylidae) on and around SEUS deep reefs indicates that these families may contain a high percentage of undescribed species (unpublished database com- piled by Martha Nizinski and colleagues, National Marine Fisheries Service Systematics Laboratory). Some of these crablike crustaceans (Figure 3 ) are abundant on the deep-reef habitats and are closely associated with the reef structure. Reed et al. (2006) also note several possibly undescribed species of invertebrates around SEUS deep-coral banks.

To date, the fish communities of shelf-edge and slope reefs are the best documented faunal group. As with the invertebrates, historical data are inadequate to characterize the ichthyofauna of deep reefs. The continental shelf subtropical reef ecosystem appears to support generally similar reef-fish assemblages from the northeastern Gulf of Mexico to Cape Hatteras (excluding southern Florida) and is the basis for
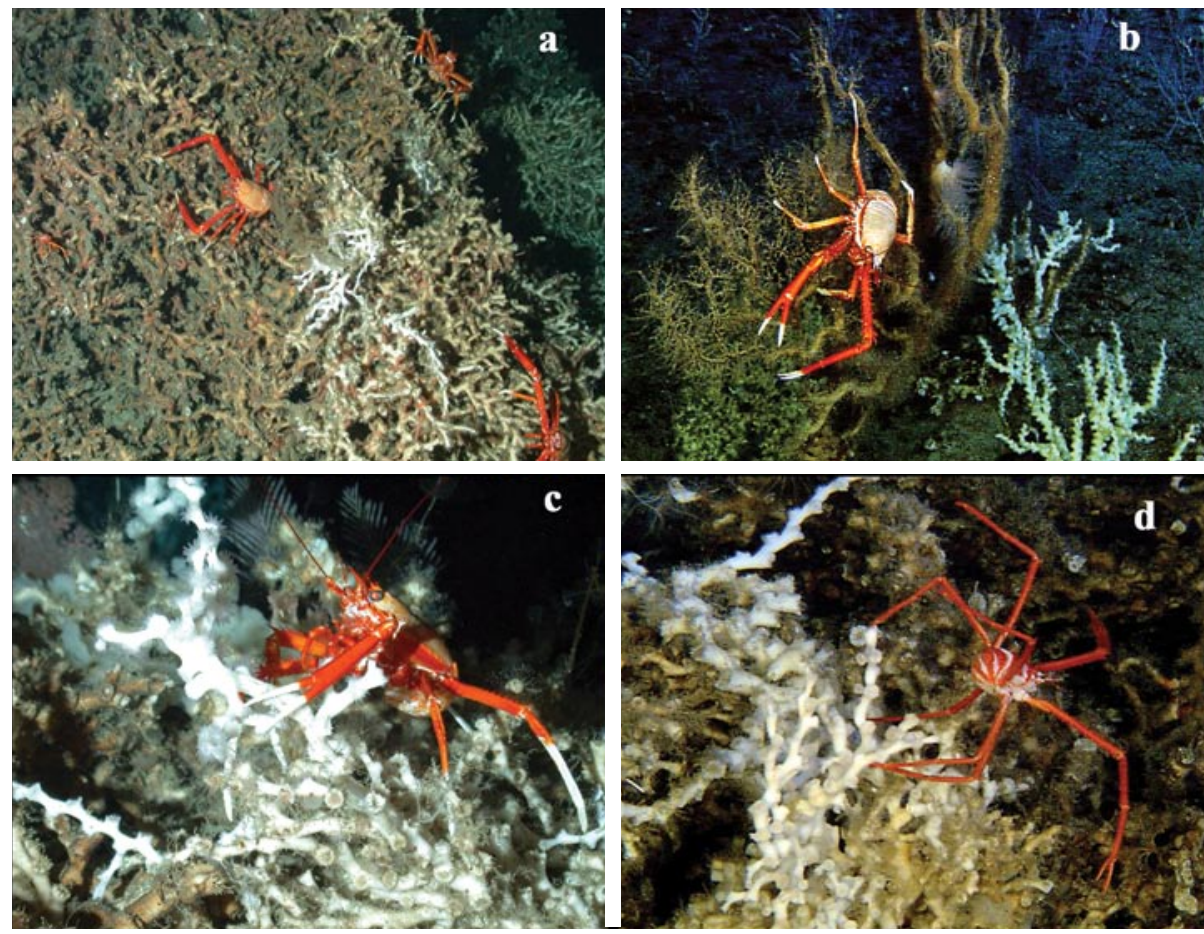

Figure 3. Squat lobsters, especially the galatheid Eumunida picta ( $a, b, c)$ are common on deep-coral habitats off the southeastern United States. Several related species, like Gastroptychus salvadori (d), are also closely associated with the corals and deep-reef structure. 
an economically important fishery. On these reefs, there seems to be a trend of increasing species richness with depth to about $80 \mathrm{~m}$, below which species richness declines. On an average dive during summer, I have observed that about 28-35 reef-fish species might be observed on a moderate-profile SEUS hardground at 20-34-m depth, compared with an average of 31 (2.4 standard error [SE]) species observed per dive at 60-100-m depth (Quattrini and Ross, 2006) and nine (0.5 SE) species at 370-800-m depth (Ross and Quattrini, 2007). Variation in species richness on shelf hardgrounds is more extreme in cold seasons, with the inshore reefs $(<30 \mathrm{~m})$ losing most of their subtropical fauna. The apparent community stability and higher species richness on shelf-edge hardbottoms probably result from moderation of the benthic environment by the Gulf Stream. Additionally, it appears that the fish communities are more dense and species-rich on reefs with higher (i.e., taller) profiles and more complex structure on both shelf and slope reefs. Regardless of the observation that on reefs the number of fish species declines with increasing depth, within any depth zone the reef habitat hosts a unique community and seems to concentrate fishes (Figure 4).

Investigations of shelf-edge and slope systems continue to reveal species that were not previously known to the area (Quattrini and Ross, 2006; Caruso et al. 2007; Ross and Quattrini, 2007). Surprisingly, we also discovered new fish species in these moderate depths not far offshore. We collected a new mid-water liparid (snailfish) at The Point (Chernova and Stein, 2004), and in 2006, we collected a new hag-
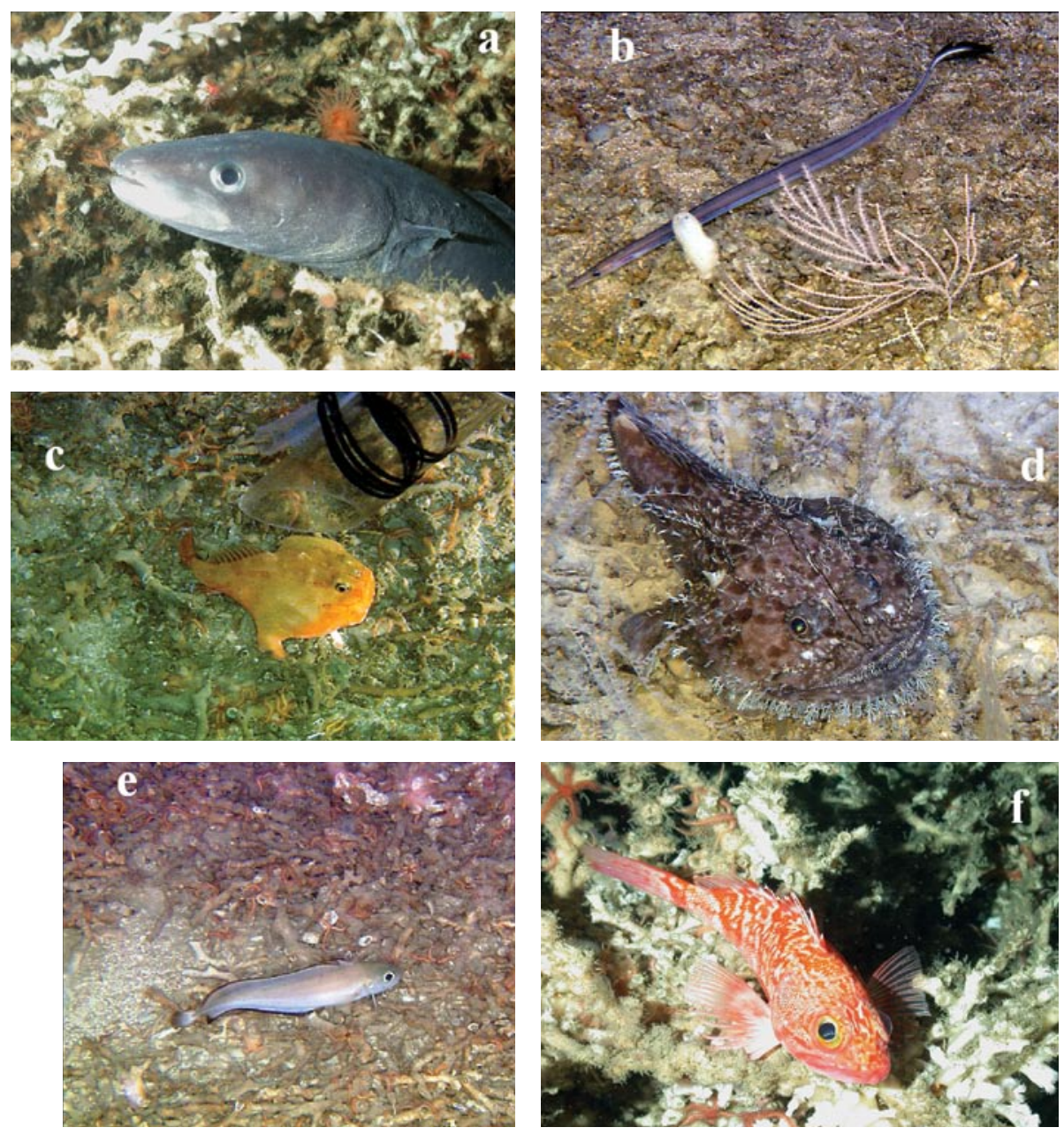

Figure 4. Common fishes around deep-coral habitats off the southeastern United States. The conger eel, Conger oceanicus (a), rarely leaves the shelter of corals, while the duckbill eel, Nettenchelys exoria (b) usually swims around reef surfaces. The gaper, Chaunax stigmaeus (c) and the related goosefish, Lophiodes beroe (d) commonly rest on coral rubble around reef bases. Laemonema barbatulum (e) occupies a variety of habitats, but the blackbelly rosefish, Helicolenus dactylopterus (f), seems to prefer reef structure. Fishes in b, c, and d were newly reported in the SEUS region.

fish (Fernholm and Quattrini, in press) and a new ophichthid eel (McCosker and Ross, 2007) on or near deep-coral habitats. Our studies on the shelf added 27 fish species previously not recorded as far north as North Carolina (Quattrini and Ross, 2006). Also, an unusually high proportion (19\%) of the 99 fish species documented on SEUS slope reefs represent extensions of their known depth or geographic limits (Ross and Quattrini,
2007). To date, this number of fish species is the highest yet recorded around deep-coral reefs, and supports the suggestion that the SEUS may contain more deep-reef habitat than comparable slope areas (Hain and Corcoran, 2004). These data concerning new species and distributional records for perhaps the bestknown marine animal group emphasize the fact that these slope ecosystems were (and still are) poorly studied. 


\section{COMPARISONS ALONG}

THE SEUS SLOPE

Previous models of deep-sea (> $200 \mathrm{~m}$ ) communities argue for distinct depth zonation, especially on the slope, but relative consistency of communities along isobaths (Haedrich, 1997). Despite early suggestions that direct observations provide better data for deep-sea communities (Merrett and Marshall, 1981), most of the data that underlie long-standing deep-sea paradigms resulted from remote (ship-based), often highly variable and biased sampling (e.g., trawls, dredges). Ideally, data covering wide temporal and spatial scales would be collected with similar gear and protocols, but this often does not happen.

Data from more directed and specific sampling, especially using submersibles and remotely operated vehicles (ROVs), indicate that instead of uniform depth-banded communities, slope fish communities are more heterogeneous. Particularly with fishes, our research indicates that there may be several different groupings of slope communities variously resulting from zoogeographic effects (range limits), environmental conditions, and habitat differences (Sulak and Ross, 1996; Moser et al., 1996; Ross and Quattrini, 2007). The fish community at The Point canyon system off Cape Hatteras is quite different (smaller individuals, fewer large species) from that to the north on the Middle Atlantic Bight slope (Sulak and Ross, 1996) and also differs from those to the south. These differences seem to be related to zoogeography (some slope fishes reach their northern and southern distribution limits near Cape Hatteras) and environmental effects (Sulak and Ross, 1996; Moser et al., 1996). The fish differ- ences at The Point reflect other unique biological and physical aspects of this area, such as high benthic productivity, unusually dense infauna, interfacing of several major currents, and upwelling (Diaz et al., 1994).

It seems apparent that there are isolat- seem to diverge from those off the SEUS. Preliminary genetic analysis of Lophelia pertusa population structure from the Gulf of Mexico to North Carolina reveals unexpected differentiation among samples (Cheryl Morrison, US Geological Survey, pers. comm., 2007). Other inver-

\section{Our research group hopes to continue}

to incorporate advanced technology (submersibles, ROVs, landers, monitoring devices) into our arsenal of tools to study continental slope habitats.

ing (or structuring) mechanisms in the deep sea (at least at slope depths) that force and maintain distinct local communities. Recent work of the author and UNCW colleague Andrea Quattrini on fishes associated with deep reefs of the SEUS slope suggests that different community structures seem related to depth, location (latitude), and/or habitat type. Deep-reef fish communities (370-800-m depth) on the Blake Plateau (from Cape Lookout, North Carolina, to off Cape Canaveral, Florida) have little in common with reef fishes of the shelf or fish communities in adjacent deeper waters (> 1000-m depth). Furthermore, these slope communities exhibit subgroupings; North Carolina deep coralbank fish assemblages are different from those to the south, and those on the central Blake Plateau are different from those off Cape Canaveral. Central Gulf of Mexico deep-coral fish communities also tebrates on the deep-coral habitats also seem to display regional patterns, but this observation requires confirmation. Similar community heterogeneity was also apparent in deep Gulf of Mexico cold-seep invertebrates, where organisms grouped by geographic locations, but the three locations examined were at quite different depths (Cordes et al., 2007). Depth or trophic input may exert the greatest influences on western Atlantic and Gulf of Mexico cold-seep communities (Cordes et al., 2007). Whatever it is that influences the structure of Lophelia and other invertebrate communities may also play a role in structuring the demersal slope reef-fish communities of the region. Discovering the mechanisms that control community structure will be difficult, but rewarding, and should lead to a much greater understanding of the interplay between slope biota and abiotic factors. 


\section{REGIONAL MANAGEMENT}

Management of deep-water resources and habitats has been particularly active in the SEUS. Two major initiatives to protect vulnerable deep-reef habitats and the resources they support were recently initiated by the South Atlantic Fishery Management Council (SAFMC, see http://www.safmc.net/ ecosystem/home/EcosystemHome/ tabid/435/Default.aspx). Eight Marine Protected Areas (MPAs) ranged along the shelf edge of the SEUS (see above Web site) were recently approved by the SAFMC in order to protect the snapper-grouper-porgy fishery complex and its hardground habitats. While MPAs can be an excellent management tool, most of these proposed MPA areas lacked predesignation data on habitats or fishery resources. The little information available (SEAMAP-SA, 2001; Quattrini and Ross, 2006, and recent research by NOAA Fisheries) indicates that these MPAs contain more nonreef than reef habitat. The SAFMC should be applauded for moving forward with proactive fishery management; however, without adequate knowledge of pre-MPA conditions and with future monitoring uncertain, the ability to judge the effectiveness of these MPAs is questionable. The second proposal by the SAFMC illustrates a very rapid pathway from research data to management based on those data. Using ongoing research of J.K. Reed of Harbor Branch Oceanographic Institution and the author (largely funded through the NOAA Office of Ocean Exploration and Research), the SAFMC proposed four areas covering a large part of the SEUS slope from North Carolina to south Florida to be Habitat Areas of Particular
Concern (HAPCs) for deep-sea corals

(Figure 5). This sweeping proposal, currently under review, may have extensive implications for future research on and utilization of deep-water areas off the SEUS.

\section{FUTURE RESEARCH}

In our technologically advanced society and at a time when increased knowledge of Earth's ocean is critical, it is unfortunate that we have so few tools readily available to advance our under-

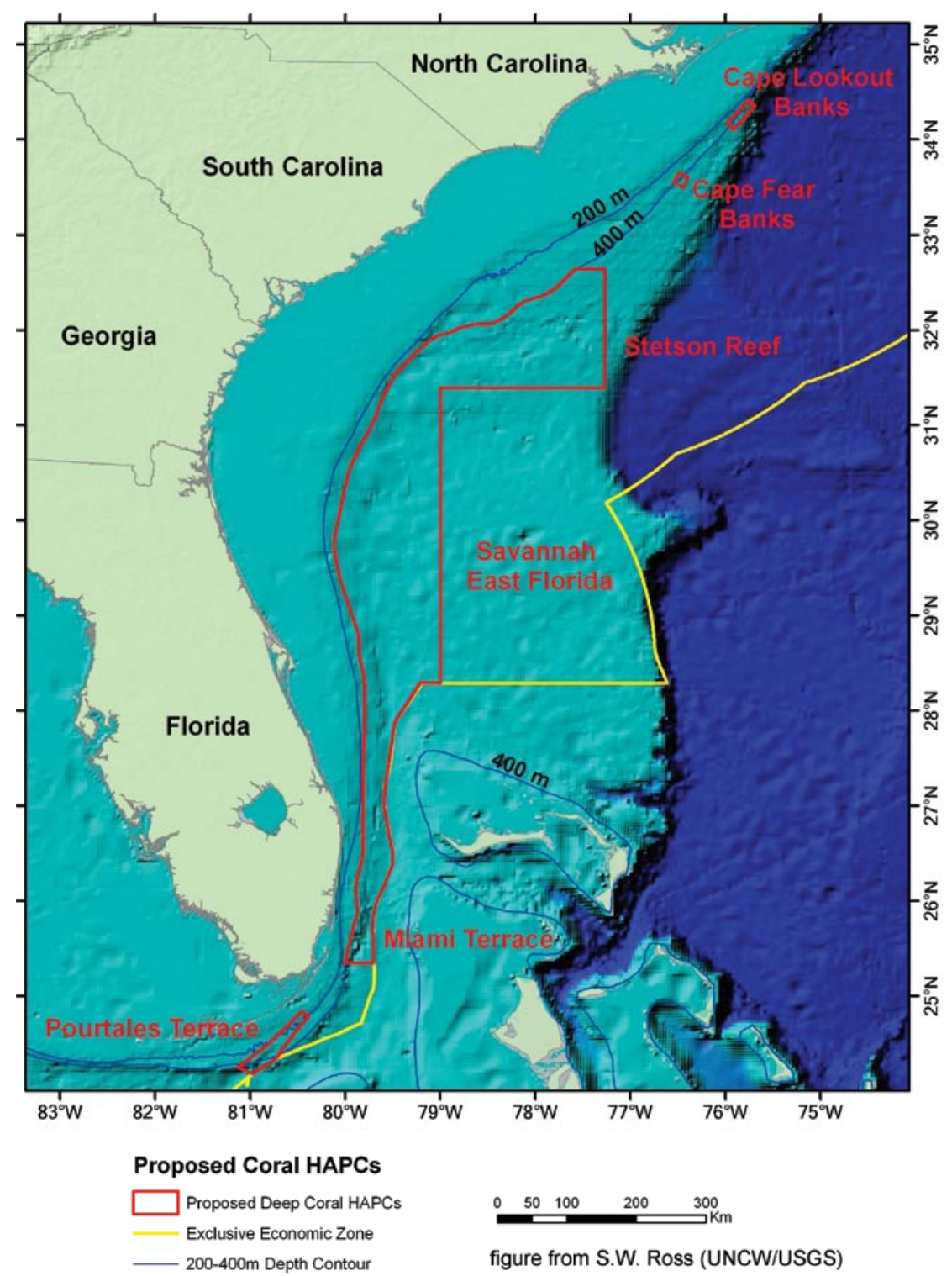

Figure 5. Four areas (outlined in red) of deep-sea coral habitat off the southeastern United States recently proposed as Habitat Areas of Particular Concern (HAPC) by the South Atlantic Fishery Management Council. These areas contain large amounts of deep-sea corals as well as most of the areas examined by researchers. These proposed HAPCs were based on data collected by author Ross and J. K. Reed of Harbor Branch Oceanographic Institution, and they are currently under review. 
standing and management of marine ecosystems. Many researchers note that submersibles and ROVs are the best methods for collecting data in many deep-sea habitats, yet such tools are rare, expensive, and some of those available are outdated. When such devices are used to collect deep-sea fauna, researchers, who are accustomed to collections mangled by nets and dredges, praise the quality of the samples. Multibeam mapping systems, autonomous underwater vehicles, and advanced monitoring instruments exist, but are not widely used. The argument that these instruments are too expensive is often based on false economy. During my first multibeam mapping cruise off the SEUS, I learned more concerning the distribution and topography of deepcoral areas in about 30 hours of mapping (Figure 2) than in the previous six years using more standard methods. Our research time would have been far more efficient and productive had maps of this detail been available when we began our work. Instead, these cruises had to devote valuable research time to locate and map potential study sites. Our research group hopes to continue to incorporate advanced technology (submersibles, ROVs, landers, monitoring devices) into our arsenal of tools to study continental slope habitats.

Despite the progress made in basic biology and ecology of SEUS deep-water ecosystems, significant data gaps remain, particularly in depths $>200 \mathrm{~m}$. The large number of new discoveries in this region illustrates how poorly the area was (and still is) known biologically and indicates that we are just beginning to appreciate the biodiversity here, especially that supported by deep-sea coral habitats.
Our future projects will concentrate on exploring the biodiversity of deep-sea coral habitats, as well as developing an understanding of how the communities of these systems are structured.

\section{ACKNOWLEDGMENTS}

NOAA Office of Ocean Exploration

(grants to S.W. Ross, lead PI) largely supported fieldwork and some data analyses. The North Carolina legislature supported some cruises and analyses. The NOAA Undersea Research Center at UNCW has been supportive of our research and funded our multibeam mapping projects. I thank the US Geological Survey, particularly G.D. Brewer and K.J. Sulak, for a variety of contributions. Minerals Management Service (through G. Boland), Environmental Defense (through D.N. Rader), and the South Atlantic Fishery Management Council (through R. Pugliese) contributed to these projects. I thank co-PIs M.S. Nizinski (NOAA), C.L. Morrison (USGS), and E. Baird (North Carolina Museum of Natural Sciences) for their dedication and contributions to our projects. A.M. Quattrini (UNCW) assisted in all aspects of these studies. I thank J.H. Caruso, J.M. Roberts, and A.M. Quattrini for helpful manuscript reviews. A. Howard graciously donated his time to assist with photography and videography. I thank Harbor Branch Oceanographic Institution personnel for assisting with numerous cruises. R/V Cape Hatteras missions were sponsored by the Duke/UNC Oceanographic Consortium (to S.W. Ross), and I thank that ship's personnel for excellent support. I thank the personnel of R/V Dan Moore and the NOAA ship Nancy Foster for their contributions. 四

\section{REFERENCES}

Anderson, W.W., J.W. Gehringer, and E. Cohen. 1956. Physical oceanographic, biological, and chemical data, South Atlantic Coast of the United States, M/V Theodore N. Gill cruise 1. US Department of the Interior, US Fish and Wildlife Service. Special Scientific Report: Fisheries No. 178, 160 pp.

Atkinson L.P., L.J. Pietrafesa, and E.E. Hofmann. 1982. An evaluation of nutrient sources to Onslow Bay, North Carolina. Journal of Marine Research 40:679-699.

Atkinson, L.P., D.W. Menzel, and K.A. Bush, eds. 1985. Oceanography of the Southeastern U.S. Continental Shelf. Coastal and Estuarine Sciences 2. American Geophysical Union, Washington, DC, 156 pp.

Avent, R.M., M.E. King, and R.H. Gore. 1977. Topographic and faunal studies of shelf-edge prominences off the central eastern Florida coast. Internationale revue gesamten Hydrobiologie 62:185-208.

Bane, J.M., Jr., L.P. Attkinson, and D.A. Brooks. 2001. Gulf Stream physical oceanography at the Charleston Bump: Deflection, bimodality, meanders, and upwelling. Pp. 25-36 in Island in the Stream: Oceanography and Fisheries of the Charleston Bump. G.R. Sedberry, ed., American Fisheries Society Symposium 25, Bethesda, MD.

Bauer, J.E., D.J. DeMaster, D.J. Repeta, and P.G. Verity, eds. 2002. Biogeochemistry and cycling of carbon in the northwest Atlantic continental margin: Findings of the Ocean Margins Program. Deep-Sea Research Part II 49:4,271-4,709.

Borowski, W.S., C.K. Paull, and W. Ussler III. 1997. Carbon cycling within the upper methanogenic zone of continental rise sediments: An example from the methane-rich sediments overlying the Blake Ridge gas hydrate deposits. Marine Chemistry 57:299-311.

Bullis, H.R., and J.R. Thompson. 1965. Collections by the exploratory fishing vessels Oregon, Silver Bay, Combat, and Pelican made during 1956-1960 in the southwestern North Atlantic. US Department of the Interior, US Fish and Wildlife Service. Special Scientific Report: Fisheries No. 510, 130 pp.

Cairns, S.D. 2006. Studies on western Atlantic Octocorallia (Coelenterata: Anthozoa). Part 6: The genera Primnoella Gray, 1858; Thouarella Gray, 1870; Dasystenella Versluys, 1906. Proceedings of the Biological Society of Washington 119:161-194.

Cairns, S.D., and F.M. Bayer. 2004a. Studies on western Atlantic Octocorallia (Coelenterata: Anthozoa): Part 4, The genus Paracalyptrophora Kinoshita, 1908. Proceedings of the Biological Society of Washington 117:114-139.

Cairns, S.D., and F.M. Bayer. 2004b. Studies on western Atlantic Octocorallia (Coelenterata: Anthozoa): Part 5, The genera Plumarella Gray, 1870; Acanthoprimnoa, n. gen.; and Candidella Bayer, 1954. Proceedings of the Biological Society of Washington 117:447-487.

Caruso, J.H., S.W. Ross, K.J. Sulak, and G.R. Sedberry. 2007. Deep-water chaunacid and lophiid 
anglerfishes (Pisces: Lophiiformes) off the Southeastern United States. Journal of Fish Biology 70:1,015-1,026.

Chernova, N.V., and D.L. Stein. 2004. A remarkable new species of Psednos (Teleostei: Liparidae) from the western North Atlantic Ocean. Fishery Bulletin 102:245-250.

Cordes, E.E., S.L. Carney, S. Hourdez, R.S. Carney, J.M. Brooks, and C.R. Fisher. 2007. Cold seeps of the deep Gulf of Mexico: Community structure and biogeographic comparisons to Atlantic equatorial belt seep communities. Deep-Sea Research Part I 54:637-653.

Diaz, R.J., J.A. Blake, and G.R. Cutter Jr., eds. 1994. Input, accumulation and cycling of materials on the continental slope off Cape Hatteras. Deep-Sea Research Part II 41(4-6):707-982.

Fernholm, B., and A.M. Quattrini. In press. A new species of hagfish (Myxinidae: Eptatretus) associated with deep-sea coral habitat in the Western North Atlantic. Copeia.

Gass, S. 2003. Conservation of Deep-Sea Corals in Atlantic Canada. World Wildlife Fund. Toronto, Canada. 57 pp.

Gorsline, D.S. 1963. Bottom sediments of the Atlantic shelf and slope off the southern United States. The Journal of Geology 71:422-440.

Guinotte J.M., J. Orr, S. Cairns, A. Freiwald, L. Morgan, and R. George. 2006. Will human-induced changes in seawater chemistry alter the distribution of deep-sea scleractinian corals? Frontiers in Ecology and the Environment 4:141-146.

Haedrich, R.L. 1997. Distribution and population ecology. Pp. 79-114 in Deep-Sea Fishes. D.J. Randall and A.P. Farrell, eds, Academic Press, New York.

Hain S., and E. Corcoran, eds. 2004. The status of the cold-water coral reefs of the world. Pp. 115-135 in Status of Coral Reefs of the World: 2004. Vol. 1. C. Wilkinson, ed., Australian Institute of Marine Science Perth, Western Australia.

Henry, L-A., M.S. Nizinski, and S.W. Ross. In press. Diversity, distribution, and biogeography of hydroid assemblages collected from deep-water coral habitats off the southeastern United States. Deep-Sea Research Part I.

Lee, T.N., J.A. Yoder, and L.P. Atkinson. 1991. Gulf Stream frontal eddy influence on productivity of the southeastern U.S. continental shelf. Journal of Geophysical Research 96:22,191-22,205.

Levin, L.A., J.P. Barry, H. Felbeck, C.R. Smith, and C.M. Young, eds. 2007. Advances in vent, seep, whale- and wood-fall biology. Marine Ecology Special Issue 28(1):1-241.

Lumsden, S.E., T.F. Hourigan, T.F. Bruckner, and G. Dorr (eds.). 2007. The State of Deep Coral Ecosystems of the United States. NOAA Technical Memorandum CRCP-3. Silver Spring, MD. 365 pp.

Macintyre, I.G., and J.D. Milliman. 1970. Physiographic features on the outer shelf and upper slope, Atlantic continental margin, southeastern United States. Bulletin of the Geological Society of America 81:2,577-2,598.
Mathews, T.D., and O. Pashuk. 1986. Summer and winter hydrography of the U.S. South Atlantic Bight (1973-1979). Journal of Coastal Research 2:311-336.

McCosker, J.E., and S.W. Ross. 2007. A new deepwater species of the snake eel genus Ophichthus (Anguilliformes: Ophichthidae) from North Carolina. Copeia 2007(4):783-787.

Merrett, N.R., and N.B. Marshall. 1981. Observations on the ecology of deep-sea bottom-living fishes collected off northwest Africa $\left(08^{\circ}-27^{\circ} \mathrm{N}\right)$. Progress in Oceanography 9:185-244.

Morgan, L.E., C-F. Tsao, and J.M. Guinotte. 2006. Status of Deep Sea Corals in US Waters, with Recommendations for their Conservation and Management. Marine Conservation Biology Institute, Bellevue, WA. 64 pp.

Moser, M.L., S.W. Ross, and K.J. Sulak. 1996. Metabolic responses to hypoxia of Lycenchelys verrillii (wolf eelpout) and Glyptocephalus cynoglossus (witch flounder): sedentary bottom fishes of the Hatteras/ Virginia Middle Slope. Marine Ecology Progress Series 114:57-61.

Neumann, A.C., J.W. Kofoed, and G. Keller. 1977. Lithoherms in the Straits of Florida. Geology 5:4-10.

Paull, C.K., A.C. Neumann, B.A. am Ende, W. Ussler III, and N.M. Rodriguez. 2000. Lithoherms on the Florida-Hatteras slope. Marine Geology 166:83-101.

Pietrafesa, L.J. 1983. Shelfbreak circulation, fronts and physical oceanography: East and west coast perspectives. Pp. 233-250 in The Shelfbreak: Critical Interface on Continental Margins. Society of Economic Paleontologists and Mineralogists Special Publication 33. Tulsa, OK.

Popenoe, P., and F.T. Manheim. 2001. Origin and history of the Charleston Bump: Geological formations, currents, bottom conditions, and their relationship to wreckfish habitats on the Blake Plateau. Pp. 43-93 in Island in the Stream: Oceanography and Fisheries of the Charleston Bump. G.R. Sedberry, ed, American Fisheries Society Symposium 25, Bethesda, MD.

Pratt, R.M. 1968. Atlantic continental shelf and slope of the United States: Physiography and sediments of the deep-sea basin. Geological Survey Professional Paper 529-B, 44 pp.

Pratt, R.M., and B.C. Heezen. 1964. Topography of the Blake Plateau. Deep-Sea Research 11:721-728.

Quattrini, A.M., and S.W. Ross. 2006. Fishes associated with North Carolina shelf-edge hardbottoms and initial assessment of a proposed marine protected area. Bulletin of Marine Science 79:137-163.

Reed, J.K., D.C. Weaver, and S.A. Pomponi. 2006. Habitat and fauna of deep-water Lophelia pertusa coral reefs off the southeastern U.S.: Blake Plateau, Straits of Florida, and Gulf of Mexico. Bulletin of Marine Science 78:343-375.

Riggs, S.R., S.W. Snyder, A.C. Hine, and D.L. Mearns. 1996. Hardbottom morphology and relationship to the geologic framework: Mid-Atlantic continental shelf. Journal of Sedimentary Research 66:830-846.

Roberts, J.M., A.J. Wheeler, and A. Freiwald. 2006.

Reefs of the deep: The biology and geology of coldwater coral ecosystems. Science 312:543-547.

Ross S.W., E.F. Aschenbach III, and J. Ott. 2001. Literature and data inventory related to the Hatteras middle slope ("The Point") area off North Carolina. Occasional Papers of the NC State Museum of Natural Sciences and the NC Biological Survey No. 13. Raleigh, NC. 360 pp.

Ross, S.W., and A.M. Quattrini. 2007. The fish fauna associated with deep coral banks off the southeastern United States. Deep-Sea Research Part I 54:975-1,007.

Ross, S.W., and M.S. Nizinski. 2007. State of deep coral ecosystems in the U.S. southeast region: Cape Hatteras to southeastern Florida. Pp. 233-270 in Lumsden, S.E., T.F. Hourigan, T.F. Bruckner, and G. Dorr (eds.). The State of Deep Coral Ecosystems of the United States. NOAA Technical Memorandum CRCP-3. Silver Spring, MD.

Schlee, J.S., W.P. Dillon, and J.A. Grow. 1979. Structure of the continental slope off the eastern United States. Pp. 95-117 in Geology of Continental Slopes. L.J. Doyle and O.H. Pilkey, eds, Society of Economic Paleontologists and Mineralogists Special Publication 27, Tulsa, OK.

SEAMAP-SA. 2001. Distribution of Bottom Habitats on the Continental Shelf from North Carolina through the Florida Keys. SEAMAP-SA Bottom Mapping Workgroup, Atlantic States Marine Fisheries Commission, Washington, DC, 166 pp.

Stetson, T.R., D.F. Squires, and R.M. Pratt. 1962. Coral banks occurring in deep water on the Blake Plateau. American Museum Novitates 2114:1-39.

Sulak, K.J., and S.W. Ross. 1996. Lilliputian bottom fish fauna of the Hatteras upper middle continental slope. Journal of Fish Biology 49 (Suppl. A):91-113.

Thompson, M.J., and L.E. Gilliland. 1980. Topographic mapping of shelf edge prominences off southeastern Florida. Southeastern Geology 21:155-164.

Uchupi, E. 1967. The continental margin south of Cape Hatteras, North Carolina: Shallow structure. Southeastern Geology 8:155-177.

Van Dover, C.L., P. Aharon, J.M. Bernhard, E. Caylor, M. Doerries, W. Flickinger, W. Gilhooly, S.K. Goffredi, K.E. Knick, S.A. Macko, and others. 2003. Blake Ridge methane seeps: Characterization of a soft-sediment, chemosynthetically based ecosystem. Deep-Sea Research Part I 50:281-300.

Zarudzki, E.F.K., and E. Uchupi. 1968. Organic reef alignments on the continental margin south of Cape Hatteras. Geological Society of America Bulletin 79:1,867-1,870. 